\title{
Engineering and Economic Evaluation Perspective in the Production of NiO Nanoparticles
}

\author{
Friska Apriliana ${ }^{\mathrm{a}, 1}$, Asep Bayu Dani Nandiyanto a,2,* \\ a Departemen Pendidikan Kimia, Fakultas Pendidikan Matematika dan Ilmu Pengetahuan Alam, Universitas Pendidikan Indonesia, Jl. Dr. Setiabudi No.229, \\ Bandung 40154, Indonesia \\ ${ }^{1}$ friskaapr13@gmail.com, ${ }^{2}$ nandiyanto@upi.edu* \\ * corresponding author
}

\section{ARTICLE INFO}

Article history

Received November 11, 2019

Revised December 11, 2019

Accepted December 17, 2019

\section{Keywords}

Economic evaluation

Industrial scale

$\mathrm{NiO}$ nanoparticles

Co-precipitation method

\section{ABSTRACT}

Nickel oxide $(\mathrm{NiO})$ nanoparticles have been proven and can be used in a variety of important applications. The purpose of this research was to evaluate the production process of $\mathrm{NiO}$ nanoparticles using the industrial co-precipitation method in terms of engineering and economic evaluation. Specifically, research was conducted by varying raw materials, product selling prices (GPM), equipment prices, and number of employees, which are compared with several economic parameters such as total investment cost (TIC), gross profit margin (GPM), break even point (BEP), payback period (PBP), net present value (NPV), and cumulative net present value (CNPV). The results showed that the PBP analysis showed that the investment would be profitable after more than 4 years with minimum product sales (GPM) of at least $90 \%$ and an increase in the price of raw materials no more than $15 \%$ of the ideal price. From this economic evaluation analysis, we can conclude that this project is feasible to run.

This is an open access article under the CC-BY-SA license.

\section{Introduction}

Nowadays, nanomaterials are widely applied in various fields. One example of nanomaterials that are currently widely used is nickel oxide nanoparticles (NiO). These nanomaterials show many unique optical, electrical, magnetic and chemical properties [1]. NiO can be used in important applications such as catalysts, gas sensors, magnetic materials, electro chromic films, battery cathodes, and super capacitors [2-4].

Several methods have been developed by researchers for the synthesis of nickel oxide nanoparticles. Examples are the co-precipitation method [5], the sol-gel method [6], the green method [7], the reaction between nickel chloride and hydrazine [8], low pressure spray pyrolysis [9], the surfactant mediated method [10], the process simple liquid phase [11], complexation precipitation method [12] and other techniques [13-15]. Of the various methods, the co-precipitation method is the best method for producing $\mathrm{NiO}$ nanoparticles on an industrial scale. This method is easy to use because the raw materials used are easily available and inexpensive.

In this study, we did research the industrial production process of $\mathrm{NiO}$ nanoparticles in terms of engineering and economic evaluation. The synthesis of existing $\mathrm{NiO}$ nanoparticles is only discussed for laboratory scale production. There is no information about economic evaluation on the industrial scale of $\mathrm{NiO}$ nanoparticles. Economic evaluation is very important because it is related to further studies to increase production. Economic evaluation of the chemical industry is a form of quantitative assessment of what is expected and desired by the community to carry out the investment process in a project [16]. To get a feasibility study, the data is calculated to get the maximum results of $\mathrm{NiO}$ fabrication that can be applied on an industrial scale. In addition, this research is important to help in making a decision whether the fabrication of $\mathrm{NiO}$ nanoparticles is profitable or not. Also, this study can be used to suggest ways to optimize projects and to benefit 
economic growth. We do economic variation on several factors that influence the scale of the $\mathrm{NiO}$ nanoparticles industry production.

\section{Method}

\subsection{Energy and Mass Balance Analysis}

To calculate energy and mass balance based on Figure 1 showing the process of producing $\mathrm{NiO}$ nanoparticles on an industrial scale, the synthesis of these nanoparticles requires several assumptions:

(i). The process is carried out based on the co-precipitation method,

(ii). Using technical $\mathrm{NiCl}_{2} \cdot 6 \mathrm{H}_{2} \mathrm{O}$,

(iii). Using technical $\mathrm{NaOH}$,

(iv). Water is obtained from river water which is treated using water treatment,

(v). Comparison of materials used in the production of $\mathrm{NiO}$ nanoparticles is estimated based on stoichiometric calculations,

(vi). The screening process is going well,

(vii). Production process for 13 hours in 1 day,

(viii). The mass of $\mathrm{NiO}$ nanoparticles is reduced by $5 \%$ during the production process transfer.

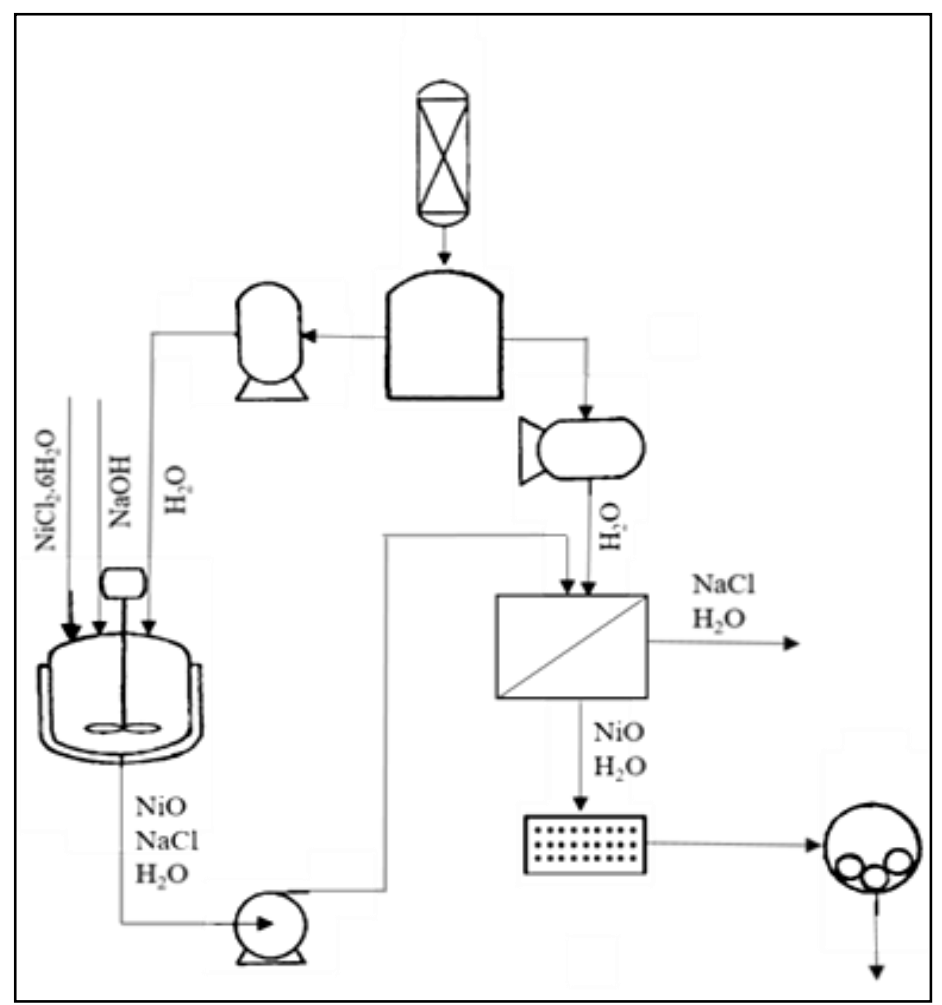

Fig 1. Scheme of the process of making $\mathrm{NiO}$ nanoparticles by the co-precipitation method

\subsection{Economic Evaluation}

In this research, the method that has been used is based on the analysis of prices of raw materials and equipment sourced from the available online web. We have analyzed the feasibility study on manufacturing $\mathrm{NiO}$ nanoparticles on an industrial scale. This feasibility study is based on simple mathematical calculations using Microsoft Excel to obtain several economic evaluation parameters; total investment cost (TIC), gross profit margin (GPM), break-even point (BEP), return period (PBP), net present value (NPV), and cumulative net present value (CNPV). Calculation of this parameter is based on the formula: 
(i). TIC is the cost to build a factory and the initial costs (equipment costs and equipment related services for equipment installation at the factory) [17],

(ii). GPM is an estimate by subtracting the cost of products sold with the cost of raw materials [18],

(iii). Calculates BEP by dividing fixed costs and profits,

(iv). PBP is calculated based on when CNPV reaches zero for the first time,

(v). NPV is the value obtained from a project that states expenditure and income by considering the opportunity cost of social capital (as discount rate i) [19],

(vi). CNPV is the calculation of the total NPV value from the beginning of the factory construction to the end of the factory operation. In short, CNPV can be obtained from the amount of cumulative financial flows each year,

$$
\mathrm{CNPV}=\sum \mathrm{NPV}
$$

Economic evaluation calculations can be obtained with the following assumptions:

(i). Production site already exists (not rent),

(ii). This project runs for 20 years,

(iii). $10 \%$ entrance tax,

(iv). 1 USD is equivalent to 14,172 IDR [20],

(v). Wages of 1 employee per year 3723.44 USD,

(vi). 1 year is equivalent to 300 days

(vii). $1 \mathrm{kWh}$ is equivalent to $0.10 \mathrm{USD}$

Then we have made several variations in changes in raw materials, product selling prices (GPM), equipment prices, and the number of employees.

\section{Results and Discussion}

\subsection{Engineering Perspective}

In this case, all the chemical compositions in the reaction have been increased up to 50,000 times based on literature [3] on the production of $\mathrm{NiO}$ nanoparticles. The increase was made to produce $\mathrm{NiO}$ nanoparticles on an industrial scale. The raw materials used in this production are listed in Table 1. After upgrading the project, we have assumed the transfer from one tool to another in the process of making nano $\mathrm{NiO}$ particle products has $5 \%$ shrinkage so that this reaction produces $471.55625 \mathrm{~kg}$ per day and rounded up to $471 \mathrm{~kg}$ per day a day.

Table 1. Raw materials used

\begin{tabular}{ccc}
\hline $\mathrm{NiCl}_{2.6 H_{2}} \mathrm{O}(\mathbf{k g})$ & $\mathbf{H}_{2} \mathbf{O}(\mathbf{L})$ & $\mathbf{N a O H}(\mathbf{k g})$ \\
\hline 297.06 & 12.500 & 1.065 \\
\hline
\end{tabular}

The tools used in the production of $\mathrm{NiO}$ nanoparticles are reactors with $1.000 \mathrm{~L}$ capacity, pumps, water treatment, tanks, filtration, ovens, and grinding. Figure 1 shows the process of producing $\mathrm{NiO}$ nanoparticles on an industrial scale. All raw materials are loaded and reacted in the reactor. Water is obtained from rivers that are treated using water treatment. Then the reaction results are separated using a filtration to produce residues and filtrate. The residue is taken and dried in the oven. To produce $\mathrm{NiO}$ nanoparticles, a grinding tool is used to produce nanoparticles products [21].

\subsection{Economic Evaluation}

\section{1) Ideal Conditions}

Figure 2 shows a graph of the ideal conditions of the relationship between CNPV/Investment on the $\mathrm{y}$ axis and life time (year) on the $\mathrm{x}$ axis. The graph was obtained from the final evaluation results in the form of a CNPV graph. The curve shows a decrease in CNPV/Investments in the first to second years. Then, there was an increase in the $3^{\text {rd }}$ to $20^{\text {th }}$ years. This project takes 4 years to reach the payback period (PBP) point. 


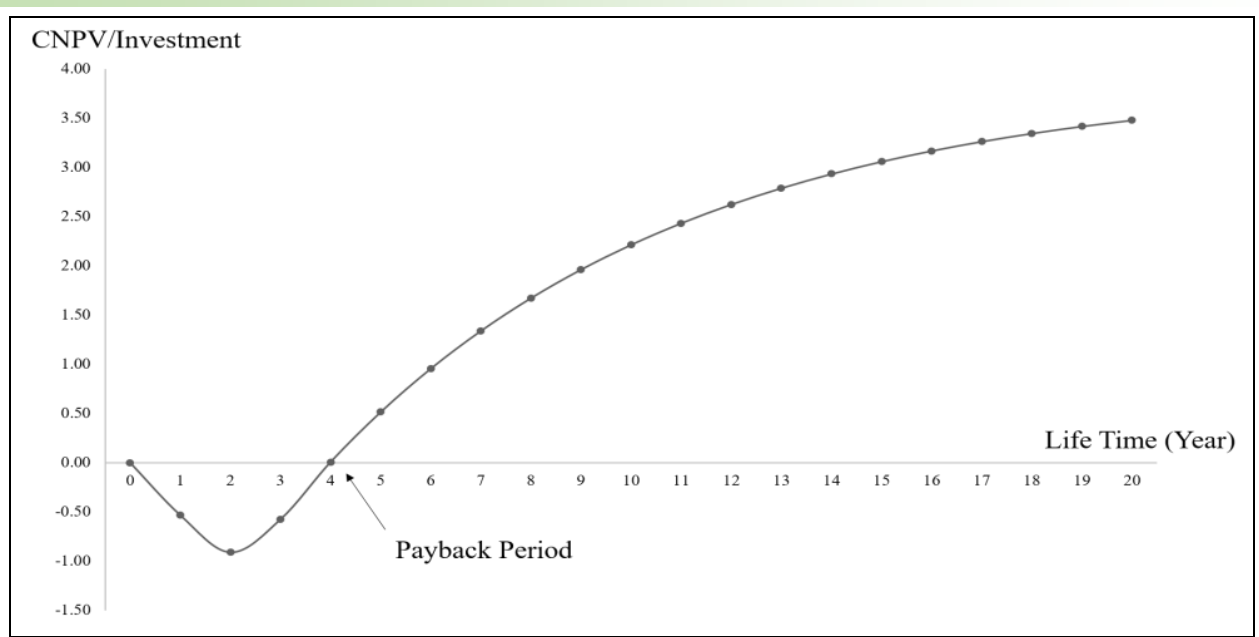

Fig 2. Ideal condition for CNPV/Investment to life time (Year)

By calculating the length of the project for 20 years, the results obtained show a decrease in the graph in years 0 to 2 decreased due to project needs. Even so, the project experienced an increase in the $3^{\text {rd }}$ year and beyond. PBP analysis shows that the investment be profitable after more than 4 years. This project takes not too long to get back the initial investment. Thus, the production of $\mathrm{NiO}$ nanoparticles on an industrial scale is profitable [22].

\section{2) Variation in Changes in Prices of Raw Materials}

Figure 3 shows changes in raw materials prices in the manufacture of $\mathrm{NiO}$ nanoparticles on an industrial scale. The graph explains the relationship between CNPV/Investment on the y axis and life time (year) on the $\mathrm{x}$ axis. The graph is obtained based on the results of variations in raw materials. This variation is done in 5 conditions with a difference of 5\%; 95\%, 100\% (ideal conditions), $105 \%, 110 \%$ and $115 \%$. In the first condition (RM 95\%), it shows a good change because the line is above the ideal curve. If there is a price increase as in the line below the ideal conditions line, the change has a significant difference.

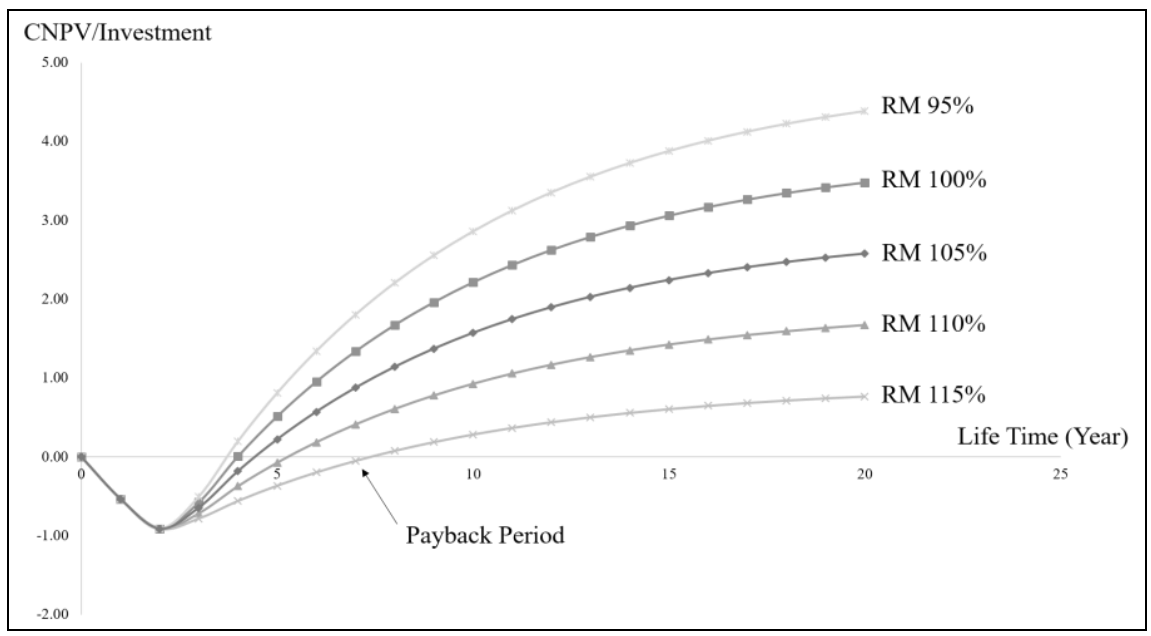

Fig 3. The curve of CNPV under various condition raw materials

In the condition of raw materials $95 \%$, this condition can occur due to a decrease in the price of raw materials than the price of raw materials ideally. It can also increase the price of raw materials $(105 \%, 110 \%$, and $115 \%)$. Can be seen from the graph, the increase in raw materials prices up to $115 \%$ is less than ideal, this is because PBP shows in the 8th year. Therefore, an increase in the price of raw materials has a negative effect on the project [23].

\section{3) Variations in GPM changes}

Figure 4 shows the variation in selling price changes (GPM). The graph shows the relationship between CNPV / Investment on the y axis and Life Time (Year) on the $\mathrm{x}$ axis. The graph is obtained from the results of 5 variations that we did. A difference of $5 \% ; 110 \%, 105 \%, 100 \%$ (ideal 
conditions), 95\%, and 90\%. Two lines above the ideal conditions line, indicate more favorable conditions. However, the selling price is more expensive than the ideal effect on market sales. As well as two lines below the ideal conditions line indicates a decrease in CNPV/Investments and this is less than ideal. Can be seen on the graph, PBP on the $90 \%$ GPM line shows in the $7^{\text {th }}$ year. Companies that maintain high selling prices can increase the company's net profit and vice versa. In this case, any changes in selling prices can affect the company's net profit [24]. Thus, a larger GPM means to generate greater profits compared to a small GPM if measured in the same sales value.

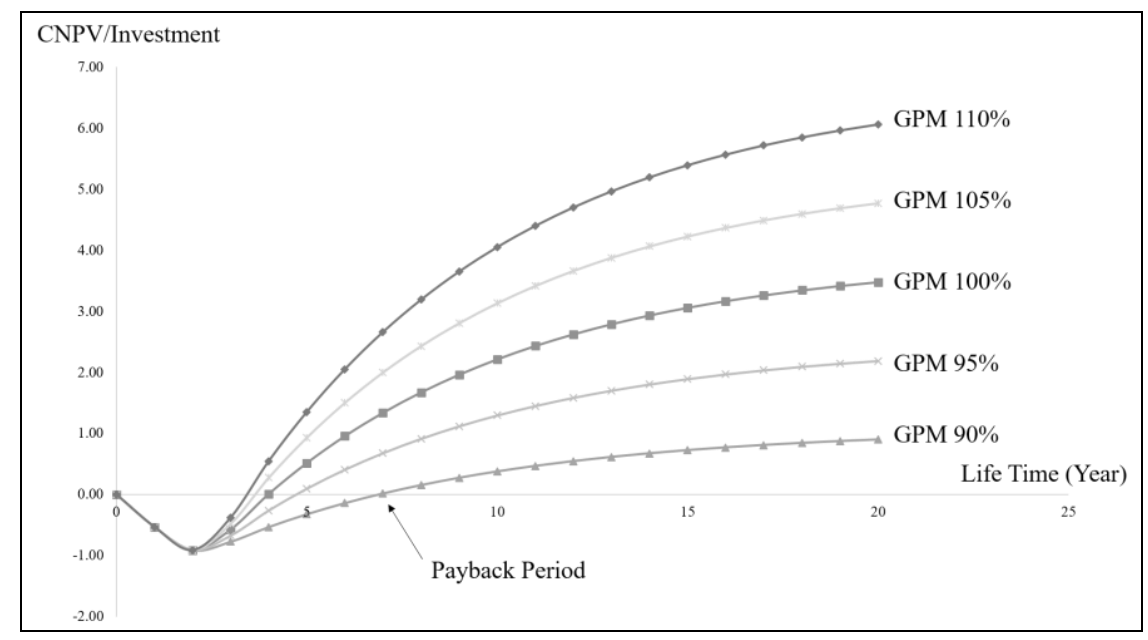

Fig 4. The curve of CNPV under various condition GPM

In the variation of the selling price (GPM), the selling price of $\mathrm{NiO}$ nanoparticles less than $90 \%$ is less recommended. This is because PBP analysis shows that investment can be profitable after more than 7 years which makes this project less attractive to industrial investors. The unattractive condition is because investors took profits too long. From the results of the payback analysis this period can be chosen with a shorter payback period. Where, the payback period can be interpreted as a period that is needed to be able to recoup investment expenditure by using proceeds or net cash flows [25]. In order to get a shorter return on investment, a smaller PBP value is chosen.

\section{4) Variations in Equipment Price Changes}

Figure 5 shows a graph of changes in equipment prices. This change was made fewer than 5 conditions, namely $100 \%, 110 \%, 120 \%, 130 \%$, and $140 \%$. The relationship contained in the graph is between CNPV/Investment on the y axis to life time (year) on the $\mathrm{x}$ axis. From this graph, changes in equipment prices do not significantly influence changes in CNPV/Investment. However, changes in equipment prices must be considered because they can affect the initial year of the $\mathrm{NiO}$ nanoparticles project. At a $140 \%$ change in equipment prices, PBP value in the 5th year, PBP values with ideal conditions differ by 1 year.

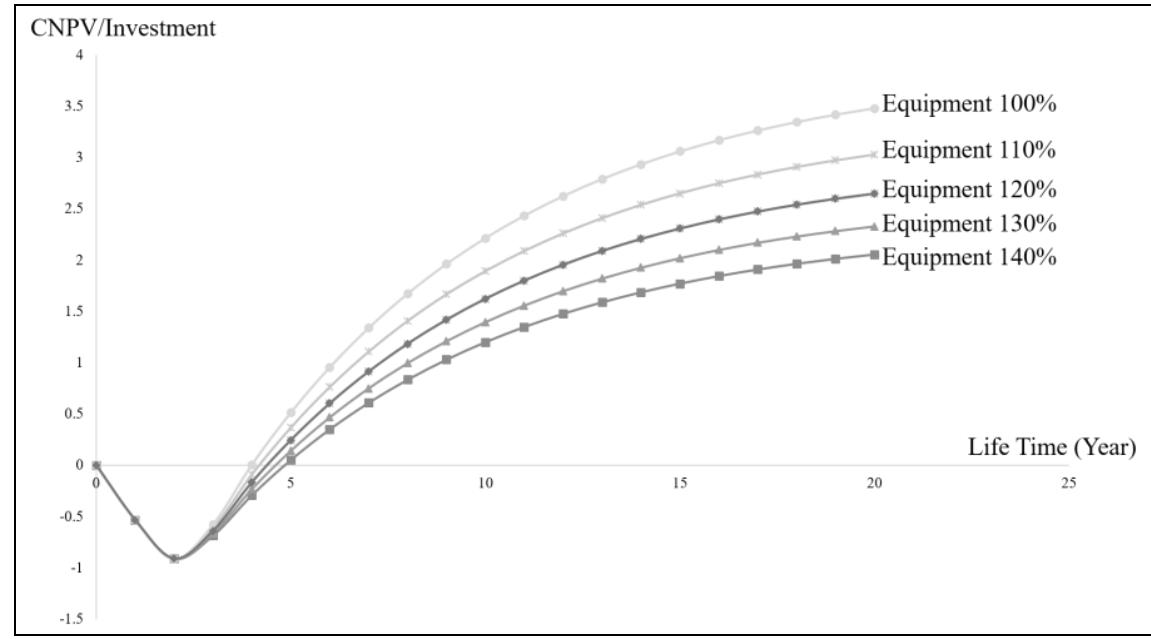

Fig 5. The curve of CNPV under various condition equipment 


\section{5) Variation of Change in Number of Employees}

Figure 6 shows the change in the number of employees in the $\mathrm{NiO}$ nanoparticles production industry. The graph explains the relationship between CNPV/Investment on the y axis and life time (year) on the $\mathrm{x}$ axis. The graph is obtained based on the results of variations in the number of employees' changes in 5 conditions. Each condition has a difference in the number of 4 employees. Changes in the number of employees are not too significant.

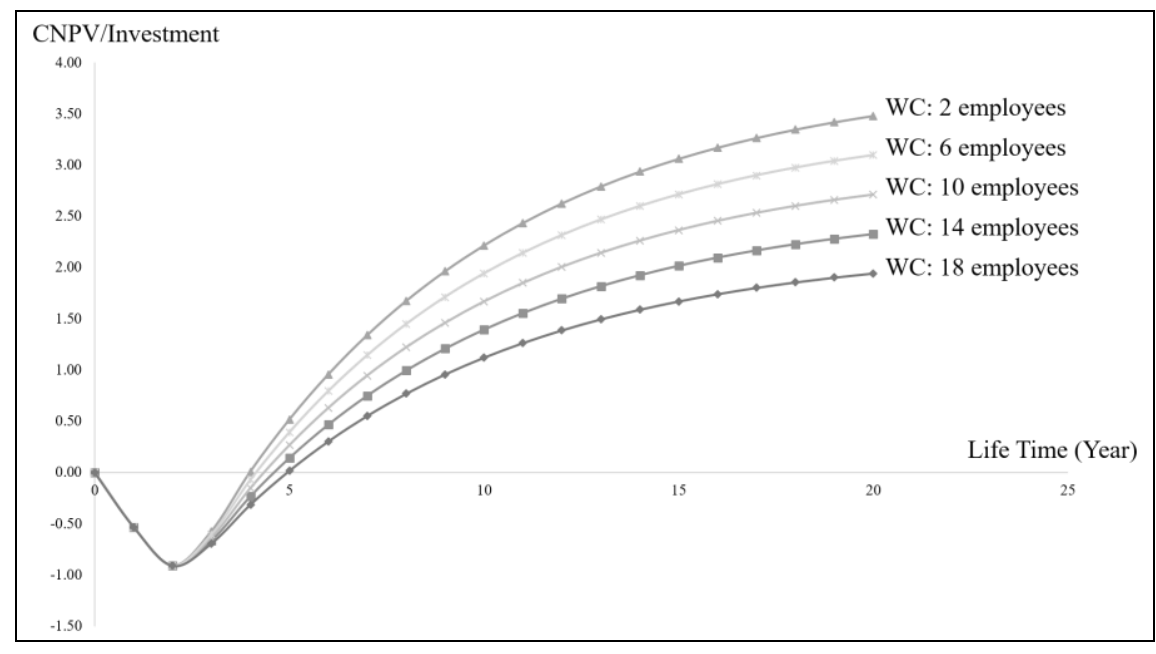

Fig 6. The curve of CNPV under various condition working capital

The number of employees in this industry does not significantly influence. However, on the change in the number of employees as many as 18 employees, PBP value shows in the 7th year. That year is still a promising investment. If the output value of an industrial company increases, producers tend to increase their production capacity. Therefore, it takes a lot of employment to increase the amount of production of a company or industry. Thus, it can affect the expansion of employment [26].

\section{Conclusion}

This study shows an engineering perspective and economic evaluation in industrial scale production of $\mathrm{NiO}$ nanoparticles. The production of $\mathrm{NiO}$ nanoparticles is based on the coprecipitation method, because this method is easy and inexpensive. PBP analysis shows that investment can be profitable after more than 4 years. It could be that this project can compete with capital market standards because the investment can return in a short time. Minimum product sales (GPM) of at least $90 \%$ and an increase in the price of raw materials no more than $15 \%$ of the ideal price. From this economic evaluation analysis, we can conclude that this project is feasible to run.

\section{Acknowledgment}

We acknowledged PKM Bidang Ilmu, Bangdos, Universitas Pendidikan Indonesia.

\section{References}

[1] Moravec, P., Smolik, J., Keskinen, H., Makela, J.M., Bakardjieva, S., and Levdansky, V.V, NiOx nanoparticles synthesis by chemical vapor deposition from nickel acetylacetonate, Mater. Sci., App. 2: 258-264, 2011. https://doi: 10.4236/msa.2011.2403.

[2] Chakrabarty, S., \& Chatterjee, K, Synthesis and Optical Manifestation of NiO-Silica Nanocomposite. ISRN Nanotechnology, 2011, 1-6, 2011. https://doi.org/10.5402/2011/719027.

[3] Castro-Hurtado, I., Herrán, J., Mandayo, G. G., and Castaño, E., Studies of influence of structural properties and thickness of $\mathrm{NiO}$ thin films on formaldehyde detection, Thin Solid Films, 520(3), 947952, 2011. doi:10.1016/j.tsf.2011.04.180.

[4] Ranga Rao Pulimi, V., and Jeevanandam, P., The effect of anion on the magnetic properties of nanocrystalline $\mathrm{NiO}$ synthesized by homogeneous precipitation, Journal of Magnetism and Magnetic Materials, 321(17), 2556-2562, 2009. doi:10.1016/j.jmmm.2009.03.039. 
[5] Das, D., and Gharib, F, Cubic NiO Nanoparticles: Synthesis and Characterization, International Journal of Bio-Inorganic Hybrid Nanomaterials, 4(2), 59-64, 2015. https://doi.org/10.7508/jns.2015.02.009

[6] Zorkipli, N. N. M., Shirts, N. H. M., and Mohamad, A. A, Synthesis of NiO Nanoparticles through Solgel Method. Procedia Chemistry, 19, 626-631, 2016. https://doi.org/10.1016/j.proche.2016.03.062.

[7] Wardani, M., Yulizar, Y., Abdullah, I., and Bagus Apriandanu, D. O., Synthesis of NiO nanoparticles via green route using Ageratum conyzoides L. leaf extract and their catalytic activity, IOP Conference $\begin{array}{lllll}\text { Series: } & \text { Materials } & \text { Science }\end{array}$ https://doi.org/10.1088/1757899X/509/1012077.

[8] El-Kemary, M., Nagy, N., and El-Mehasseb, I., Nickel oxide nanoparticles: Synthesis and spectral studies of interactions with glucose, Material Science in Semiconductor Processing, 16 (6), 1747-1752, 2013. https://doi.org/10.1016/j.mssp.2013.05.018

[9] Wuled Lenggoro, I., Itoh, Y., Iida, N., and Okuyama, K., Control of size and morphology in NiO particles prepared by a low-pressure spray pyrolysis, Materials Research Bulletin, 38(14), 1819-1827, 2003. doi:10.1016/j.materresbull.2003.08.005.

[10] Wang, Y., Ma, C., Sun, X., and Li, H., Preparation of nanocrystalline metal oxide powders with the surfactant-mediated method, Inorganic Chemistry Communications, 5(10), 751-755, 2002. doi:10.1016/s1387-7003(02)00546-4.

[11]Wang, C. Bin, Gau, G. Y., Gau, S. J., Tang, C. W., and Bi, J. L., Preparation and characterization of nanosized nickel oxide, Catalysis Letters, 101(3-4), 241-247, 2005. https://doi.org/10.1007/s10562-0054899-X.

[12] Motlagh, M. M. K., Youzbashi, A. A., and Sabaghzadeh, L., Synthesis and characterization of Nickel hydroxide/ oxide nanoparticles by the complexation-precipitation method, International Journal of Physical Sciences, 6(6), 1471-1476, 2011. https://doi.org/10.5897/IJPS11.025.

[13]Tao, D. and Wei, F., New procedure towards size-homogeneous and well-dispersed nickel oxide nanoparticles of $30 \mathrm{~nm}$, Materials Letters, 58(25), 3226-3228, 2004. doi:10.1016/j.matlet.2004.06.015.

[14] Wang, Y. and Ke, J.-J., Preparation of nickel oxide powder by decomposition of basic nickel carbonate in microwave field with nickel oxide seed as a microwave absorbing additive, Materials Research Bulletin, 31(1), 55-61, 1996. doi:10.1016/0025-5408(95)00160-3.

[15] S. I. Cherrey, O. Tillement, J. M. Dubois, F. Massicot, Y. Fort, J. Ghanbaja, and S. B. Colin, Materials Science and Engineering: A. 1, 2002, 70- 75.

[16] Nandiyanto, A.B.D. and Ragadhita, R., Evaluasi Ekonomi Perancangan Pabrik Kimia. Bandung: UPI Press, 2018.

[17]Frioui, S. and Oumeddour, R., Investment and Production costs of desalination plants by the semiempirical method, Desalinitation, 223 (1-3), 457-463, 2008.

[18] Garret, D.E., Chemical engineering economics, New York: Springer Science \& Business Media, 2012.

[19]Brennan, D. and Golonka, K., New factors for capital cost estimation in evolving process designs, Chemical Engineering Research and Design, 80(6), 579-586, 2002.

[20] Bank Indonesia, Informasi Kurs, 2019. bi.go.id/moneter/informasi-kurs/transaksi-bi/default.aspx.

[21] Strambeanu, N., Demetrovici, L., and Dragos, D., Natural Sources of Nanoparticles, In Nanoparticles' Promises and Risks (pp. 9-19), Springer International Publishing, 2015.

[22] Prabowo, B., Khairunnisa, T., Bayu, A., and Nandiyanto, D., Economic Perspective in the Production of Magnetite $\left(\mathrm{Fe}_{3} \mathrm{O}_{4}\right)$ Nanoparticles by Co-precipitation Method, 2(2), 1-4, 2018.

[23] Shalahuddin, F. A., Almekahdinah, S. S., and Nandiyanto, A. B. D., Preliminary Economic Study on the Production of $\mathrm{ZnO}$ Nanoparticles Using a Sol-Gel Synthesis Method, Jurnal Kimia Terapan Indonesia, 21(1), 1-6, 2019. https://doi.org/10.14203/jkti.v21i1.407.

[24]Budi, R., Pengaruh Harga Jual Dan Biaya Operasional Terhadap Laba Bersih Pada Perusahaan Tambangan Sub Sektor Batubara Yang Terdaftar Di Bursa Efek Indonesia Periode 2010-2013, Harga 

Vol. 6, No. 2, December 2019, pp. 63-70

Jual Dan Biaya Operasional Terhadap Laba Bersih, 1-20, 2015. https://doi.org/10.4028/www.scientific.net/KEM.642.174.

[25] Bambang Riyanto, Dasar-dasar Pembelajaran Perusahaan, Yogyakarta: Penerbit BPFE, 1994.

[26] Simanjuntak, Payaman, J., Undang-Undang yang Baru tentang Serikat Pekerja/Serikat Buruh, Jakarta: Kantor Perburuhan Internasional, 2001. 